\title{
ANALISIS KESALAHAN PENULISAN HURUF KAPITAL OLEH MAHASISWA PGSD SEMESTER II KELAS 3 UNIKA SANTO THOMAS SUMATERA UTARA
}

\author{
Liana Siburian \\ Surel: lianasiburian302@yahoo.co.id
}

\begin{abstract}
This study aims to analyze the errors of capital letter writing by PGSD students in second semester of class 3. This research uses qualitative descriptive method with research subject ayaitu PGSD student of Semester II Class 3 is qualitative descriptive method. This research takes the following steps: inventory data through questionnaire, data description, and data classification. The results of the study note that every student needs to write because writing is part of student life. In order to have no problem in writing the capital letters, it is necessary to improve the writing of capital letters in the first sentence, the first letter of direct passage, the first letter of honorary title, ancestry, and religion followed by the name of the person, the first letter of the name of the nation, the tribe and the language.
\end{abstract}

Keywords: Error Analysis Capital Writing

\begin{abstract}
ABSTRAK
Penelitian ini bertujuan untuk menganalisis kesalahan penulisan huruf kapital oleh mahasiswa PGSD semester II kelas 3. Penelitian ini menggunakan metode deskriptif kualitatif dengan subjek penelitian ayaitu mahasiswa PGSD Semester II Kelas 3 adalah metode deskriptif kualitatif. Penelitian ini menempuh langkah-langkah sebagai berikut: menginventarisasi data melalui angket, deskripsi data, dan klasifikasi data. Hasil penelitian diketahui bahwa setiap mahasiswa perlu menulis karena menulis adalah bagian dari kehidupan mahasiswa. Supaya tidak masalah lagi dalam menulis hurup kapital maka perlu ditingkatkan dalam menulis hurup kapital baik dalalm penggunaan awal kalimat, huruf pertama petikan langsung, huruf pertama nama gelar kehormatan, keturunan, dan keagamaan yang diikuti nama orang, huruf pertama nama bangsa, suku dan bahasa.
\end{abstract}

Kata Kunci: Analisis Kesalahan Penulisan Huruf Kapital

\section{PENDAHULUAN}

Kehidupan manusia tidak dapat lepas dari kegiatan berbahasa. Bahasa merupakan sarana untuk berkomunikasi antarmanusia. Bahasa sebagai alat komunikasi ini, dalam rangka memenuhi sifat manusia sebagai makhluk sosial yang perlu berinteraksi dengan sesama manusia.
Bahasa dianggap sebagai alat yang paling sempurna dan mampu membawakan pikiran dan perasaan baik mengenai hal-hal yang bersifat konkrit maupun yang bersifat abstrak.

Keterampilan $r$ berbahasa
terdiri dari empat aspek, yaitu
menyimak atau mendengarkan,


berbicara, membaca, dan menulis. mahasiswa harus menguasai keempat aspek tersebut agar terampil berbahasa. Dengan demikian, pembelajaran keterampilan berbahasa di sekolah tidak hanya menekankan pada teori saja, tetapi mahasiswa dituntut untuk mampu menggunakan bahasa sebagaimana fungsinya, yaitu sebagai alat untuk berkomunikasi. Salah satu aspek berbahasa yang harus dikuasai oleh mahasiswa adalah menulis.

Bahasa sangat penting bagi manusia dalam kehidupan seharihari. Bahasa merupakan alat untuk berkomunikasi dengan orang lain, untuk itu diperlukan menggunakan bahasa. Bukan hanya bahasa yang diperlukan tetapi menulis juga diperlukan orang untuk sebagai pengantar berkomunikasi. Setiap yang kita tulis perlu juga di analisis oleh orang lain, tidak semua yang kita tulis itu menjadi benar. Untuk itu di perlukan penelitian tentang analisis kesalahan penulisan huruf kapital oleh mahasiswa PGSD semester II kelas 3 tahun pelajaran 2017/2018.

Salah satu kaidah penulisan yang sudah tergantung dalam ejaan yang disempurnakan adalah tata cara penulisan huruf kapital. Tata cara penulisan huruf kapital adalah salah satu kaidah yang paling dasar dalam ejaan yang disempurnakan, sehingga terkadang para penulis menyepelekan dalam penulisan huruf kapital. Walaupun tata cara penulisan huruf kapital adalah hal yang bersifat formal dalam penulisan, tetap saja tata cara ini dianggap yang paling penting. Dalam penulisan huruf kapital disebut juga huruf induk atau huruf miring atau secara universal disebut italic.

Menulis harus dapat menjadi kebiasaan, tanpa kebiasaan menulis maka kita akan sulis untuk menulis. Ada tiga cara yang dapat dilakukan untuk meningkatkan kemampuan menulis pada diri seseorang yaitu: 1 . Mengubah mindset atau cara pandang menulis yang tidak lagi sekedar pelajaran., melainkan perilaku, perbuatan menulis. 2 . Menjadikan menulis sebagai gaya hidup, bukan bertumpu pada minat atau bakat menulis sebagai gaya hidup itu mengasyikkan dan sangat menghibur. Kita bisa mencurahkan isi hati, perasaan, pikiran yang berkecamuk melalui tulisan, dan 3 . Terbiasa menulis memang sulit, tetapi bukan berarti tidak bisa.

Pengertian dan penggunaan huruf kapital dalam bahasa indonesia saat menulis, hendaknya perhatikanlah aturan-aturan yang berlaku sesuai dengan pedoman umum ejaan bahasa indonesia yang disempurnakan seperti penggunaan tanda baca dan penggunaan huruf kapital agar tulisan Anda menjadi tulisan yang baik dan benar.

Padahal penulisan huruf besar juga berpengaruh dalam penulisan suatu kalimat apabila kita lihat bila kita mengganti huruf besar pada penulisan kalimat dengan huruf kecil kita tidak dapat membedakan awal kalimat dengan akhir kalimatnya. Karena awal kalimatnya telah 
bercampur dengan akhir kalimatnya karena hurufnya sama.

Huruf kapital (besar) pada saat ini jarang diperhatikan penggunaanya dalam kehidupan sehari-hari, baik itu penggunaaan secara tertulis baik di instansi dalam hal ini kondisinya formal maupun yang lainnya. Kaidah penggunaannya pun seringkali dilupakan oleh kebanyakan orang. Terkadang, seorang guru pun lupa akan penggunaan huruf kapital ini. Kebanyakan orang melupakan atau tidak menggunakan kaidah ini dengan benar karena merasa terlalu banyak aturan dan tidak praktis. Padahal jika kaidah penggunaan huruf kapital ini dilakukan dengan benar, maka akan banyak manfaatnya bagi kita terutama dalam hal tulis menulis. Jika kita mengamati, kaidah penggunaan huruf kapital yang benar sering dijumpai pada surat kabar, majalah, buku pendidikan yang semuanya masih bersifat formal. Oleh karena itu, kaidah penggunaan huruf kapital yang benar sebaiknya ditanamkan sejak dini agar nantinya bermanfaat bagi kita.

Akan tetapi, masalah yang terjadi di lapangan adalah tidak semua mahasiswa mempunyai kemampuan menulis hurup kapital yang baik. Oleh sebab itu, pembinaan keterampilan menulis harus dilakukan sedini mungkin.

Keterampilan menulis harus dikuasai oleh para mahasiswa pendidikan keguruan sekolah dasar karena keterampilan ini secara langsung berkaitan dengan seluruh proses belajar mahasiswa. Keberhasilan belajar mahasiswa dalam mengikuti proses kegiatan belajar-mengajar di sekolah sangat ditentukan oleh penguasaan kemampuan menulis mereka. mahasiswa yang tidak mampu menulis dengan baik dan benar akan mengalami kesulitan dalam mengikuti kegiatan pembelajaran untuk semua mata kuliah.

Menurut Kamus Besar Bahasa Indonesia pengertian huruf kapital dipisahkan, huruf diartikan sebagai unsur abjad yang melambangkan bunyi, sedangkan kapital diartikan sebagai huruf yang berukuran lebih besar dari pada huruf biasa yang berukuran kecil dari huruf kapital. Bila digabungkan pengertian huruf kapital adalah huruf yang biasanya digunakan untuk huruf pertama dari kata pertama dalam suatu kalimat huruf pertama dari nama orang/diri dan sebagainya. Huruf kapital juga digunakan sebagai huruf pertama kalimat petikan langsung.

Huruf kapital disebut juga huruf besar. Huruf kapital adalah huruf yang berukuran dan berbentuk khusus (lebih besar dari huruf biasa), biasanya digunakan sebagai huruf pertama dari kata pertama dalam kalimat, huruf pertama nama diri, dan sebagainya.

Aturan-aturan penggunaan huruf kapital terbagi atas beberapa bagian antara lain sebagai berikut: 
a. Huruf kapital atau huruf besar dipakai sebagai huruf pertama kata pada awal kalimat

b. Huruf kapital dipakai sebagai huruf pertama petikan langsung.

c. Huruf kapital dipakai sebagai huruf pertama dalam ungkapan yang berhubungan dengan nama Tuhan dan Kitab suci, termaswuk kata ganti untuk Tuhan.

d. Huruf kapital dipakai sebagai huruf pertama nama gelar kehormatan, keturunan, dan keagamaan yang diikuti nama orang.

e. Huruf kapital dipakai sebagai huruf pertama unsure nama jabatan dan pangkat yang diikuti nama orang atau yang dipakai sebagai pengganti nama orang tertentu, nama instansi, atau nama tempat.

f. Huruf kapital dipakai sebagai huruf pertama unsur-unsur nama orang.

g. Huruf kapital sebagai huruf pertama nama bangsa, suku dan bahasa.

h. Huruf kapital dipakai sebagai huruf pertama nama tahun, bulan, hari, hari raya, dan peristiwa sejarah.

i. Huruf kapital dipakai sebagai huruf pertama nama geografi.

j. Huruf kapital dipakai sebagai huruf pertama semua unsur nama Negara, lembaga pemerintahan dan ketatanegaraan, serta nama dokumen resmi kecuali kata seperti dan. k. Huruf kapital dipakai sebagai huruf pertama setiap unsur bentuk ulang sempurna yang terdapat pada nama badan, lembaga pemerintahan dan ketatanegaraan, serta dokumen resmi.

1. Huruf kapital dipakai sebagai huruf pertama semua kata (termasuk semua unsure kata ulang sempurna) di dalam nama buku, majalah, surat kabar, dan judul karangan kecuali kata seperti di, ke, dari, dan untuk yang tidak terletak pada posisi awal.

m. Huruf kapital dipakai sebagai huruf pertama untuk singkatan nama gelar, pangkat, dan sapaan.

n. Huruf kapital dipakai sebagai huruf pertama kata petunjuk hubungan kekerabatan seperti bapak, ibu, saudara, kakak, adik, dan paman yang dipakai dalam penyapaan dan pengacuan.

Dari aturan-aturan tersebut, terdapat pula larangan tentang penggunaan huruf kapital anatara lain sebagai berikut:

a. Huruf kapital tidak dipakai sebagai huruf pertama nama gelar, kehormatan, keturunan, dan keagamaan yang tidak diikuti nama orang.

b. Huruf kapital tidak dipakai sebagai huruf pertama nama jabatan pangkat yang tidak diikuti nama orang, atau nama tempat.

c. Huruf kapital tidak dipakai sebagai huruf pertama nama bangsa suku bangsa, dan bahasa 
yang dipakai sebagai bentuk dasar kata turunan.

d. Huruf kapital tidak dipakai sebagai huruf pertama peristiwa sejarah yang tidak dipakai sebagai nama.

e. Huruf kapital tidak dipakai sebagai huruf pertama nama geografi yang digunakan sebagai nama jenis.

f. Huruf kapital tidak dipakai sebagai huruf pertama kata yang bukan nama resmi Negara, lembaga pemerintahan dan ketatanegaraan, badan, serta nama dokumen resmi.

g. Huruf kapital tidak dipakai sebagai huruf pertama kata petunjuk hubungan kekerabatan yang tidak dipakai dalam pengacuan atau penyapaan.

\section{METODE PENELITIAN}

Dalam penyusunan suatu karya tulis lebih-lebih yang bersifat ilmiah sudah barang tentu harus digunakan suatu metode yang baik, karena metode merupakan cara kerja untuk dapat memahami objek yang menjadi sasaran ilmu yang bersangkutan (Kuncaraningrat 1977:16) dengan metode yang tepat dalam memecahkan masalah dengan baik.

Menurut Nazir (1988), metode deskriptif merupakan suatu metode dalam penelitian status sekelompok manusia, suatu objek, suatu set kondisi, suatu system pemikiran ataupun suatu kelas peristiwa pada masa sekarang. Tujuan dari penelitian deskripsif ini adalah untuk membuat deskripsi, gambaran, atau lukisan secara sistematis, faktual dan akurat mengenai fakta-fakta, sifat-sifat serta hubungan antar fenomena yang diselidiki. Sedangkan menurut sugiyono (2005) menyatakan bahwa metode deskriptif adalah suatu metode yang digunakan untuk menggambarkan atau menganalisis suatu hasil penelitian tetapi tidak digunakan untuk membuat kesimpulan yang lebih luas. Menurut Whitney (1960), metode deskriptif adalah pencarian fakta dengan interpretasi yang tepat.

Metode penelitian kualitatif adalah metode untuk menyelidiki objek yang tidak dapat diukur dengan angka-angka ataupun lain yang bersifat eksak. Penelitian kualitatif juga bisa diartikan sebagai riset yang bersifat deskriptif dan cenderung menggunakan analisis dengan pendekatan induktif.

Dari metode-metode tersebut di atas yang paling tepat diterapkan untuk penelitian penulisan unsur serapan oleh mahasiswa PGSD Semester II Kelas 3 adalah metode deskriptif kualitatif. Penerapan metode tersebut dalam penelitian ini menempuh langkah-langkah sebagai berikut:

a. Menginventarisasi data melalui angket

b. Deskripsi data

c. Klasifikasi data

Sutopo (2002:36) teknik cuplikan penelitian kualitatif cenderung bersifat purposive karena dipandang lebih mampu menangkap 
kelengkapan dan kedalaman data. Arikunto (2006:139) Sampel bertujuan atau purposive sample dilakukan dengan cara mengambil subjek bukan didasarkan atas strata, random atau daerah tapi didasarkan atas ada tujuan tertentu. Teknik ini biasanya dilakukan karena beberapa pertimbangan misalnya, alasan keterbatasan waktu, tenaga, dan dana sehingga tidak dapat mengambil sample yang besar dan jauh.

Teknik penelitian dilakukan dalam rangka mengumpulkan bahanbahan penelitian ini ditempuh melalui dua tahap yaitu, tahap pertama, studi lapangan, tahap kedua, studi pustaka. Studi lapangan untuk mendapatkan penulisan unsur serapan oleh mahasiswa PGSD Semester II Kelas 3 dengan mengisi angket yang disediakan oleh penelitian. Studi pustaka dilakukan untuk mendapatkan sumber data atau kriteria serta kaidah-kaidah yang berlaku dalam penulisan unsur serapan yang baik dan benar (EYD). Sumber lain yang berkaitan dengan unsur serapan misalnya dengan membaca beberapa pustaka dan hasil penelitian.

\section{HASIL PENELITIAN DAN PEMBAHASAN}

Dari hasil penelitian berdasarkan angket tentang penulisan unsur partikel yang telah kami berikan kepada mahasiswa Prodi PGSD Semester II Kelas 3 Unika Santo Thomas Sumatera Utara sebagai objek penelitian yang berjumlah 22 orang bahwa dari hasil angket tersebut diperoleh nilai sebagai berikut:

Petunjuk Kerja:

Berilah tanda centang $(\sqrt{ })$ pada kolom "B", jika menurut Anda pernyataan itu benar dan kolom "S", jika menurut Anda pernyataan itu salah.

\begin{tabular}{l|l|l|l}
\hline No & \multicolumn{1}{|c|}{ Penyataan } & B & S \\
\hline $\mathbf{1}$ & Mira bertaya, “kapan Kakak datang?”. & & \\
\hline 2 & Dia baru saja dilantik menjadi presiden. & & \\
\hline 3 & $\begin{array}{l}\text { Calon jemaah Haji DKI akan diberangkatkan hari ini ke } \\
\text { Mekah. }\end{array}$ & & \\
\hline 4 & Para Guburnur se-Indonesia berkumpil di Bali. & & \\
\hline 5 & Kita harus menghormati Bapak dan Ibu kita & & \\
\hline 6 & "Anak itu berkata", Permisi, bolehkah saya bertanya? & & \\
\hline 7 & $\begin{array}{l}\text { Adikku menjadi pegawai kementrian di Kementrian Hukum } \\
\text { dan Ham. }\end{array}$ & & \\
\hline 8 & Dia telah menyelesaikan Asas-Asas Hukum Perdata & & \\
\hline 9 & Dia baru saja diangkat menjadi sultan & & \\
\hline 10 & "Lebih baik kita pulang sekarang," kata Andi & & \\
\hline 11 & Pendidikan guru sekolah dasar & & \\
\hline
\end{tabular}




\begin{tabular}{l|l|l|l}
\hline 12 & Usa salah satu Negara berkembang & & \\
\hline 13 & Pernahkah anda melakukan penelitian dilapangan? & & \\
\hline 14 & Shita menyelesaikan kuliahnya dan mendapat Gelar S.Pd & & \\
\hline 15 & Mereka Akan pergi naik haji tahun ini & & \\
\hline
\end{tabular}

\section{SIMPULAN}

Setiap mahasiswa perlu menulis karena menulis adalah bagian dari kehidupan mahasiswa. Supaya tidak masalah lagi dalam menulis hurup kapital maka perlu ditingkatkan dalam menulis hurup kapital baik dalam penggunaan awal kalimat, huruf pertama petikan langsung, huruf pertama nama gelar kehormatan, keturunan, dan keagamaan yang diikuti nama orang, huruf pertama nama bangsa, suku dan bahasa.

\section{DAFTAR RUJUKAN}

Arikunto \& Ahmad, 2011. Bahasa Indonesia Untuk Perguruan Tinggi. Jakarta: Kencana Perdana Media Group.

Arikunto. 1991. Prosedur Penelitian. Jakarta: PT Rineka Cipta.

Chaer, Abdul. 1998. Tata Bahasa Praktis Bahasa Indonesia. Jakarta: Rineka Cipta.

Hartanto, S. 1995. Pedoman Umum Pembentukan Istilah Dan Pedoman Umum Ejaan Bahasa Indonesia Yang

Disempurnakan (EYD). Surabaya: Penerbit INDAH Surabaya.

Moeliono, M. Anton dkk. 1998. Tata Bahasa Baku Bahasa Indonesia. Jakarta: Balai Pustaka.
Saddhono, Kundharu dan Y. Slamet. 2014. Pembelajaran dan Keterampilan Berbahasa Indonesia. Yogyakarta: Graha Ilmu.

Sutopo, H.B. 2002. Metode Penelitian Kualitatif; Dasar Teori dan Penerapannya dalam Penelitian. Surakarta: UNS Press.

Sugihastuti, 2007. Bahasa Laporan Penelitian. Yogyakarta: Pustaka Pelajar.

Tarigan, Henry Guntur. 1993. Menulis Sebagai Suatu Ketarampilan Berbahasa. Bandung: Angkasa Bandung.

Widiya. 2010. Pedoman Umum Ejaan Bahasa Indonesia Yang Disempurnakan dan Pedoman Umum Pembentukan Istilah. Bandung: Yrama Widya. 